\title{
Host-Plant Resistance and Management of Bacterial Spot of Pepper ${ }^{1}$
}

Ken Pernezny, Jeff Jones, Russell Nagata, and Nikol Havranek ${ }^{2}$

Throughout the history of bell-pepper production in Florida, bacterial spot, caused by the bacterium Xanthomonas euvesicatoria, has been one of the most serious problems facing Florida's pepper growers. The disease is characterized by leaf spots (Fig. 1) that can coalesce and result in significant premature defoliation (Fig. 2). The bacterium may also infect fruit, causing scabby lesions that render fruit unfit for market (Fig. 3).

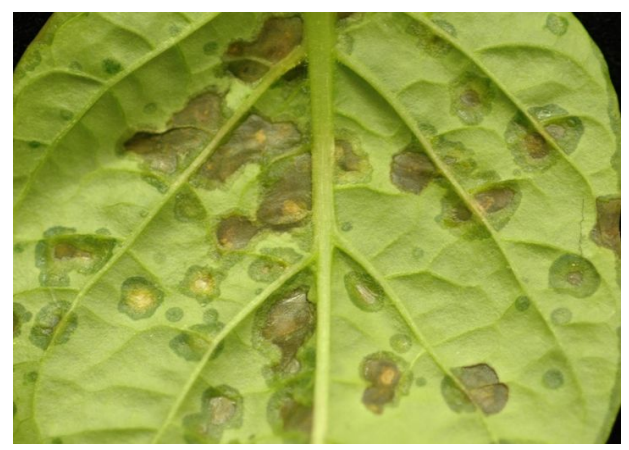

Figure 1. Newly developed bacterial spot lesions on underside of pepper leaves. Note prominent water soaking is a dominant symptom at this phase of the disease

Ten races of X. euvesicatoria have been identified worldwide. A race (identified by numbers

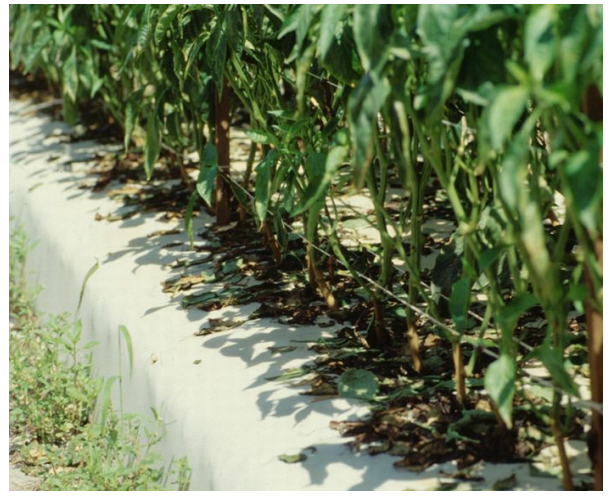

Figure 2. A commercial planting of bell pepper in Delray Beach, FL, shows severe defoliation of the lower canopy due to bacterial spot.

-- $1,2,3$, etc.) is defined by how well it can survive and grow on cultivars with or without specific genes for resistance. Host-plant resistance associated with these specific genes is based on single, dominant genes that confer resistance to specific races of the pathogen. Over the years, genes resistant to various races of X. euvesicatoria have been identified and introduced into commercial bell pepper cultivars (Table 1).

1. This document is PP255, one of a series of the Plant Pathology Department, Florida Cooperative Extension Service, Institute of Food and Agricultural Sciences, University of Florida. Original publication date, June 2008. Visit the EDIS Web Site at http://edis.ifas.ufl.edu.

2. Ken Pernezny, professor, Plant Pathology Department, Everglades Research and Education Center--Belle Glade, FL; Jeffrey Jones, professor, Plant Pathology Department, Gainesville, FL; Rusell Nagata, associate professor, Horticultural Sciences Department, Everglades Research and Education Center--Belle Glade, FL; Nikol Havranek, biological scientist, Everglades Research and Education Center--Belle Glade, FL, University of Florida, Institute of Food and Agricultural Sciences, Gainesville, FL 32611.

The Institute of Food and Agricultural Sciences (IFAS) is an Equal Opportunity Institution authorized to provide research, educational information and other services only to individuals and institutions that function with non-discrimination with respect to race, creed, color, religion, age, disability, sex, sexual orientation, marital status, national origin, political opinions or affiliations. U.S. Department of Agriculture, Cooperative Extension Service, University of Florida, IFAS, Florida A. \& M. University Cooperative Extension Program, and Boards of County Commissioners Cooperating. Larry Arrington, Dean 


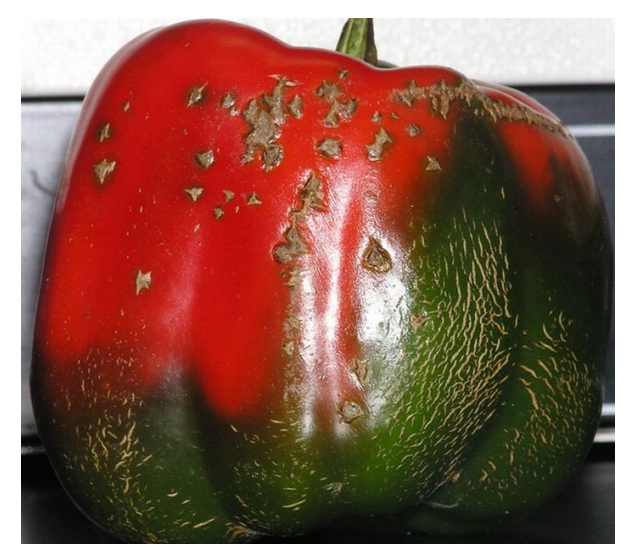

Figure 3. Scabby lesions characteristic of bacterial spot on pepper fruit.

The history of the campaign to use these resistance genes to manage bacterial spot is interesting. One curiosity of this history is that some races of X. euvesicatoria have been detected in discrete geographical areas more frequently than other races. For example, prior to 1989, race 2 was predominant in South Florida. The $B s 1$ gene, however, has been available for some time and confers a high level of resistance to race 2. (Note: Resistance genes and bacterial races are numbered in chronological order of discovery.)

Despite $B s 1$ 's highly effective resistance to race 2, some plant pathologists and breeders in Florida were reluctant to release bell pepper cultivars with the $B s 1$ gene for fear that other races (such as, for example, race 1) might appear in this area and attack these cultivars. Unfortunately, in the 1989-90 winter vegetable season in South Florida, when private seed enterprises released horticulturally desirable cultivars with the $B s 1$ gene, the worst possible outcome was realized. A sudden shift in the prevalent race from race 2 to race 1 occurred in South Florida. The race-1 strains defeated the $B s 1$ gene. As a result, major losses occurred in Florida bell pepper fields among cultivars with and without the Bsl gene.

Subsequent to the outbreak of race 1 in South Florida during 1989-90 winter vegetable season, several seed companies released cultivars with the $B s 2$ gene, which confers resistance to races 1,2 and 3 of X. euvesicatoria. We now know, however, that other races exist that can defeat $B s 2$. For example, in the summer of 1995, races 4 and 5 were destructive on peppers in North Carolina. An outbreak of race 6, which can defeat all known resistance genes $(B s 1$, $B s 2$, and Bs3), occurred in 1995 in Ohio. In the
1997-98 season in South Florida, a shift to race 6 as the dominant race occurred. As a result, serious losses occurred throughout the bell pepper industry in Florida that year. These losses were particularly troubling in regards to the newly released cultivars, in which the $B s 2$ gene conferred resistance to race 1, 2 and 3 , as breeders had not expected races other than 1, 2 and 3 to become dominate in Florida.

One approach to this seemingly bewildering problem of new races emerging that are not controlled by resistance genes has been to "pyramid" or "stack" several resistance genes within the same pepper variety. This "pyramid" method of plant breeding allows seed companies to market cultivars that have a broader spectrum of resistance against a range of races most likely to affect bell peppers grown in Florida. Numerous bell pepper varieties are now available with combined resistance to many of the 10 known races of X. euvesicatoria (Fig. 4) (Table 1). These cultivars with combined resistance to several races have been especially helpful in managing race 4 , which extension agents and researchers with the University of Floridas Institute of Food and Agricultural Sciences (IFAS) have found to be particularly aggressive and widespread throughout Florida over the last few seasons.

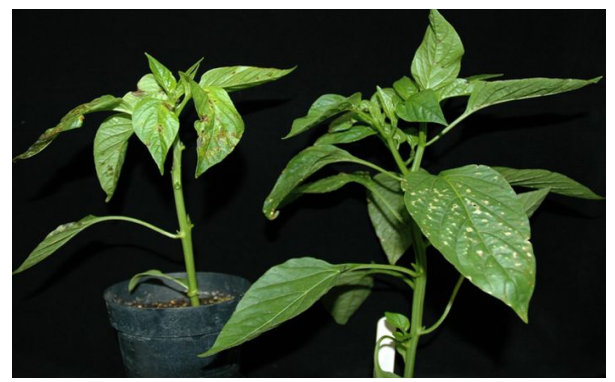

Figure 4. Typical bacterial spot (disease) reaction on bell pepper leaves [left] and resistant (hypersensitive) reaction [right].

However, these experts have also determined that race 6 has been the cause of mostly late-season outbreaks on cultivars with resistance-gene pyramids. Currently no commercial pepper variety is available with resistance to race 6 . Limited observations of race- 6 infections indicate that the onset of infection after fruit set has had a minimal impact on crop yield and quality. Serious impacts could result from race 6 if outbreaks of this race begin early in the crop cycle. 
Of course, a grower's decision to plant a particular pepper cultivar is influenced by much more than the plant's resistance to bacterial spot. High yields, large fruit size, "blockiness" (a length-to-width ratio near 1), a 4-lobe fruit architecture, and thick fruit wall are among desirable horticultural traits for bell peppers. Through the excellent extension programming in Hendry and Palm Beach counties, IFAS extension agents and researchers have been conducting extensive pepper-cultivar evaluations on commercial farms. They have identified several promising bell pepper cultivars with a pyramid of $B s 1, B s 2$, and $B s 3$ and with fairly good horticultural characteristics, as well. Nonetheless, under warm and rainy weather conditions, which are favorable for bacterial spot, these cultivars were attacked by race 6 , as noted above.

This situation, in which pathogen races appear that defeat resistance genes incorporated into commercial cultivars, might be quite frustrating. One could easily develop a sense that developing cultivars resistant to various races of $\mathrm{X}$. euvesicatoria is a never-ending battle, which plant pathologists are ultimately doomed to lose.
However, Bob Stall and Jeff Jones of IFAS have discovered a different type of resistance. This new form of resistance (sometimes called horizontal resistance) confers resistance to all races of the target pathogen. Since more than one gene is involved in horizontal resistance, and the genes are likely to be recessive, horizontal resistance is considerably more difficult for plant breeders. Yet these IFAS researchers believe horizontal resistance can ultimately revolutionize the struggle to manage bacterial spot on pepper. They find that horizontal resistance is more likely to be stable over time and less likely to fail due to the appearance of new races. Seed companies are currently working with horizontal resistance. As a result, pepper cultivars that include horizontal resistance are expected to be available in the near future.

These developments in host-plant resistance -valuable for pepper growers throughout Florida -may be of particular interest to organic farmers, who have very limited chemical-control methods available due to requirements for certifying vegetable crops as organic.

Table 1. Genes available for resistance to specific races of Xanthomonas euvesicatoria.

\begin{tabular}{|c|c|}
\hline Gene & Resistance to race: \\
\hline Bs1 & 2,5 \\
\hline Bs2 & $1,2,3,7,8$ \\
\hline Bs3 & $1,4,7,9$ \\
\hline${ }^{\star} B s 4$ & $1,3,4,6$ \\
\hline $\begin{array}{l}{ }^{*} \text { In diff } \\
\text { 1Professo } \\
\text { FL } \\
\text { 2Professo } \\
\text { 3Associat } \\
\text { Center, Be } \\
\text { 4Biologica }\end{array}$ & $\begin{array}{l}\text { earch and Education } \\
\text { ter, Belle Glade, FL }\end{array}$ \\
\hline
\end{tabular}

